\title{
Designing Portable Shopping Trolley with Scooter Using Kansei Engineering Approach
}

\author{
Alex Kisanjani ${ }^{\# 1}$, Hari Purnomo ${ }^{\# 2}$ \\ ${ }^{\#}$ Faculty of Industrial Technology, Department of Industrial Engineering, Universitas Islam Indonesia, Yogyakarta, Indonesia \\ E-mail: ${ }^{1} 15916202 @$ students.uii.ac.id; ${ }^{2}$ haripurnomo@uii.ac.id
}

\begin{abstract}
The role of the shopping center or mall becomes more important because of people likely to consider quality, service, and safety in shopping as their priorities. People will not have these when shopping in traditional markets. Shopping trolleys are transported tool that makes it easy for customers to shop, to carry purchased items in large quantities from one place to another at once. The problem that often occurs in the mall is not providing shopping trolleys that covers all areas of shopping, so do in Rita Pasaraya Tegal. Customers should hand-carry their purchased items. If the condition happened continuously, it would cause nerve trauma (carpal tunnel syndrome). Another problem is customer's tiredness when shopping because they have to walk around the vastness of all shopping areas in Rita Pasaraya Tegal. This study aims to design a portable shopping trolley with a scooter to minimize such impact. Furthermore, the Kansei engineering method is used to determine the parameter of design. This method can translate human's expression or needs into design so that the product fits what customers wish. The result of this research founds that five Kansei words represent customer's desire in designing portable shopping trolley with a scooter; fine design, not big, strong, easy to handle, and safe. Moreover, the concept design made has already meet customers wishes with Z-value of Stuart Maxwell test of marginal homogeneity greater than 0.05 .
\end{abstract}

Keywords - shopping trolley; Kansei engineering method; carpal tunnel syndrome; tiredness.

\section{INTRODUCTION}

Shopping center or commonly called mall is a place for retailers that sell various kinds of goods and services from personal needs to household needs [1]. The role of the mall becomes more and more important because nowadays people likely to prioritize the product's quality, hospitality, and safety while shopping. These conditions will not be met when shopping in traditional markets. Besides its main function as a shopping center, the mall also serves as a recreational facility.

The shopping trolley is a kind of conveyance that makes customer easier to shop. With this tool, consumers can carry purchased goods in large quantities easily from here to there all at once. The often occurred problem; it's not usual for a mall to provide shopping trolleys in all shopping areas. Just like in Rita Pasaraya Tegal, management only provides shopping trolleys in the area of basic needs/supermarket. As a result, consumers will have difficulty in carrying the goods they bought when they shop in other areas of the mall. It's usual for customers to hand-carry their purchased items. This is potentially caused health problem, such as paresthesia (pins and needles syndrome), and while the shopping activity is held for a long time, it can cause nerve trauma called carpal tunnel syndrome [2]. Rita Pasaraya
Tegal is a five stories shopping center. The building is vast that can cause fatigues problem while shopping for customers who want to explore every floors and corner.

The number of research about designing and developing shopping trolley which purposed to minimize and reduce fatigue is quite a lot. One of the research is about the development of shopping trolley attached with motorized seat [3]. Another research is about the development of shopping trolley with various additional features and functions [4]. These two kinds of trolleys are facilitated the customers for easier shopping time, but the problem is trolley's body. The big body of these trolley design will cause inefficiency for storing and carrying. Another research is the development of shopping trolley with additional navigation system for product's tracking [5]. This system aims to facilitate the customers for tracking and finding the product easier.

Based on these studies, researchers are interested in designing a portable shopping trolley with scooter attached. Portable means simplicity for storing and carrying while attaching scooter means reducing fatigue caused by long walking while shopping. Attaching scooter also providing simplicity because it doesn't form a big and heavy trolley, but easier to use. Kansei Engineering method used in this research is a product designing and developing method 
which able to translate human's psychological process towards either products in the markets or a new product's concept [6]. Kansei Engineering method also has the capability in translating human's expression and wants into a design, so that the product fits what customer's wish [7].

\section{MATERIAL AND METHOD}

\section{A. Population and Sample}

The population of this research is all customers and visitors in Rita Pasaraya Tegal. Samples of this research are 30 customers who shop in Rita Pasaraya Tegal [8]. Samples are conducted by using a random sampling technique with criteria: man or woman from 20-40 years old.

\section{B. Research Procedure}

The procedure in this research is following the steps from Kansei Engineering method [9]. Kansai Engineering method consists of 4 main steps, as in the flowchart below [10]:

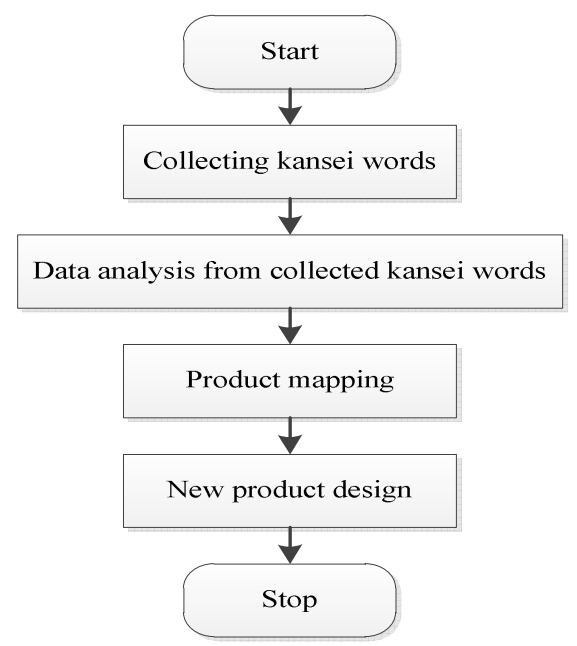

Fig. 1 Steps of Kansei engineering type 1

The first step is collecting the Kansei words. It is collected by distributing the questionnaire to customers in Rita Pasaraya Tegal. The second step is analyzing the collected Kansei words as the main data. The Kansei words are analyzed with a statistical analysis method. The third step is product mapping. Kansei words which already passed the statistical test then divided into several stages, so that they can describe the characteristic of the design that will be created. The last step is to design the new product. After getting the needed specification for the new design, it is visualized into a product image.

\section{Data Analysis}

This research is using 4 statistical test in analyzing the data. The first and second tests are validity and reliability. This is used to find out the level of validity and consistency of every collected Kansei words. The requirement for collected Kansei words to be said as valid is $R_{\text {value }}>R_{\text {table }}$ [11], while the requirement for data reliability is when Cronbach alpha $>0.7$ [12], [13]. The third test is a factor analysis test. This is used to divide the Kansei words into several groups or factors [14], [15]. This test is held after validity and reliability test. The first step in factor analysis is evaluating Kansei words by using Significance value of Bartlett's Test of Sphericity and Kaiser-Meyer-Olkin (KMO) value. The requirement of respectively values allowed is $<0.05$ and $>0.5$ [14], [15]. The test is followed by grouping the factors using eigenvalues [14]. The fourth test is the Stuart Maxwell test of Marginal Homogeneity. This is used to find out the gap between design concept and the customer's wants. This test is done after the concept design visualized into a form of the product. The requirements of value allowed in this test is $\mathrm{Z}>0.05$ [16].

\section{RESULTS AND DISCUSSION}

\section{A. Kansei Words}

The first step is collecting the Kansei words. Kansei words are collected by distributing the random questionnaire to 30 customers and visitors of Rita Pasaraya Tegal. 8 Kansei words obtained from the questionnaire can be seen in Table I below:

TABLE I

KANSEI WORDS

\begin{tabular}{|l|l|}
\hline No. & Kansei Words \\
\hline 1 & Fine design \\
\hline 2 & Not big \\
\hline 3 & Strong \\
\hline 4 & Easy to handle \\
\hline 5 & Light \\
\hline 6 & Comfortable \\
\hline 7 & Safe \\
\hline 8 & Simple \\
\hline
\end{tabular}

After 8 Kansei words are obtained from the questionnaire, the next step is validity and reliability test. Validity test is done to find the validity level of each Kansei words, while reliability test is done to find the consistency level of each Kansei words. The result of validity and reliability test can be seen in Table II below:

TABLE II

RESULT OF VALIDITY TEST AND RELIABILITY TEST

\begin{tabular}{|l|l|l|l|}
\hline \multicolumn{4}{|c|}{ Validity } \\
\hline No. & Kansei Words & $\begin{array}{l}\text { Correlation } \\
\text { Coefficient }\end{array}$ & Conclusion \\
\hline 1 & Fine design & 0.706 & Valid \\
\hline 2 & Not big & 0.590 & Valid \\
\hline 3 & Strong & 0.756 & Valid \\
\hline 4 & Easy to handle & 0.761 & Valid \\
\hline 5 & Light & 0.036 & Not valid \\
\hline 6 & Comfortable & 0.181 & Not valid \\
\hline 7 & Safe & 0.756 & Valid \\
\hline 8 & Simple & 0.257 & Not valid \\
\hline & & Reliability & \\
\hline No. & Kansei Words & Cronbach Alpha & Conclusion \\
\hline 1 & Fine design & 0.709 & Reliable \\
\hline 2 & Not big & 0.736 & Reliable \\
\hline 3 & Strong & 0.715 & Reliable \\
\hline 4 & Easy to handle & 0.714 & Reliable \\
\hline 5 & Light & 0.818 & Reliable \\
\hline 6 & Comfortable & 0.796 & Reliable \\
\hline 7 & Safe & 0.716 & Reliable \\
\hline 8 & Simple & 0.794 & Reliable \\
\hline
\end{tabular}


The result obtained five valid and reliable Kansei words based on validity and reliability test. These Kansei words are valid with the value of $R_{\text {value }}>0.3610\left(R_{\text {value }}>R_{\text {table }}\right)$, and reliable with the value of Cronbach alpha $>0.7$. Therefore, the valid and reliable Kansei words become a reference in product designing.

\section{B. Factor Analysis}

Factor analysis is used to divide Kansei words into groups or factors [14], [15]. In other words, factor analysis summarizes Kansei words to facilitate the mapping of a product concept. The first step in factor analysis is evaluating Kansei words by using Significance value of Bartlett's Test of Sphericity and Kaiser-Meyer-Olkin (KMO) value, which can be seen in Table III below:

TABLE III

RESULT OF KMO AND BARTLETT'S TEST

\begin{tabular}{|l|l|}
\hline Indicator of Evaluation & Value \\
\hline KMO & 0.789 \\
\hline $\begin{array}{l}\text { The significance value of Bartlett's Test } \\
\text { of Sphericity }\end{array}$ & 0.000 \\
\hline
\end{tabular}

The significance value of Bartlett's Test of Sphericity is $<0.05$; it shows that analyzed variables (Kansei words) can be used in this research [14], [15]. Kaiser-Meyer-Olkin (KMO) value is $>0.5$; it shows that the samples taken are adequate for factor analysis [14], [15].

Since Bartlett's Test of Sphericity and Kaiser-MeyerOlkin (KMO) have met the requirement, the analysis is going further by grouping the Kansei words into several factors, which can be seen in Table IV.

TABLE IV

RESUlT OF TOTAL EIGENVALUE

\begin{tabular}{|l|l|}
\hline Component & Total of Eigenvalue \\
\hline 1 & 3.565 \\
\hline 2 & 0.841 \\
\hline 3 & 0.264 \\
\hline 4 & 0.169 \\
\hline 5 & 0.161 \\
\hline
\end{tabular}

Factors grouping is seen from the total of eigenvalue. Allowed value is $>1$ of eigenvalue in total [14]. In Table III, there is only one $>1$ eigenvalue in total; it shows that only one factor formed. Factors grouping can be seen in Table V below:

TABLE V

RESULT OF FACTORS GROUPING

\begin{tabular}{|l|l|}
\hline Kansei Words & Factor 1 \\
\hline Fine design & 0.836 \\
\hline Not big & 0.773 \\
\hline Strong & 0.880 \\
\hline Easy to handle & 0.860 \\
\hline Safe & 0.869 \\
\hline
\end{tabular}

\section{Products Mapping}

Products mapping is used to describe Kansei words to be more specific and detail. Kansei words are divided into several stages to illustrate the character of a design concept that will be created.

The characteristics of these five Kansei words is described as:

1) Fine design: trolley's body is a cylinder with $4 \mathrm{~cm}$ in diameter and $103 \mathrm{~cm}$ in height. Trolley's height is based on an anthropometrical characteristic of Indonesian people in the level of elbow's height while standing, by using 50th percentile (average number). The purpose of using 50th percentile is for a comfortable reason for every people. Considerably several researches had been conducted by using 50th percentile as the groundwork to determine trolley's height [17], [18]. Trolley's color is silver, matched with aluminum color. Moreover, trolley's body is diminished to $60 \mathrm{~cm}$ for easier storing. Trolley's basket is pouch with $30 \mathrm{~cm}$ of diameter and $45 \mathrm{~cm}$ in height. Trolley's diameter and height is according to its volume, which is 32 liters. The color is brown, according to the customer's want. Trolley's handlebar is a cylinder with $3 \mathrm{~cm}$ in diameter. The length of the handlebar is $36 \mathrm{~cm}$, based on anthropometric of shoulder's width of Indonesian people by using 50th percentile (average number). The purpose of using 50th percentile is for the comfortable reason of the handlebar so that it fits for everyone. A lot of researches used 50th percentile as the basis of determining handlebar's length [17], [18]. Handlebar's color is silver, matched with aluminum color. Trolley's wheels are $5 \mathrm{~cm}$ in diameter, coated with rubber so not slippery. Scooter's footing is a rectangle in 28 $\mathrm{cm} \times 8 \mathrm{~cm}$. The size of footing refers to anthropometric of sole's size of Indonesian people. Because scooter's footing is included in the dimensions of space, the percentile used is 95 [19]. It aims for people with big feet so that they can use it comfortably. The length of the handgrip is $36 \mathrm{~cm}$, matched with the handlebar's length. The handgrip is made of foam with brown color; the color is matched customer's wants

2) Not big: this Kansei words related to the volume of the shopping basket. Customers want average size which not so big and not too small so that the size is determined as 32 liters.

3) Strong: structure, footing, handlebar, and trolley wheels using aluminum because it has strong physical properties and lightweight [20]. Trolley basket uses nylon material because it has strong physical properties, subtle, and durable [21]. Also, the use of nylon material is aimed to basket trolley so that it can be folded. Then, the trolley wheel is coated with rubber material, so that it is not slippery when used.

4) Easy to handle: The portable shopping trolley uses three wheels consisting of 1 front wheel and two wheels on the back. It purposed to keep the portable shopping trolley balanced when used and ease in its usage. Handlebar uses straight handlebar that is connected to the wheel.

5) Safe: Portable shopping trolley is using the hand brake. The goal is for security and safety, and for addition is also to make it easier to control.

The result of product mapping can be seen in Figure 2 . 


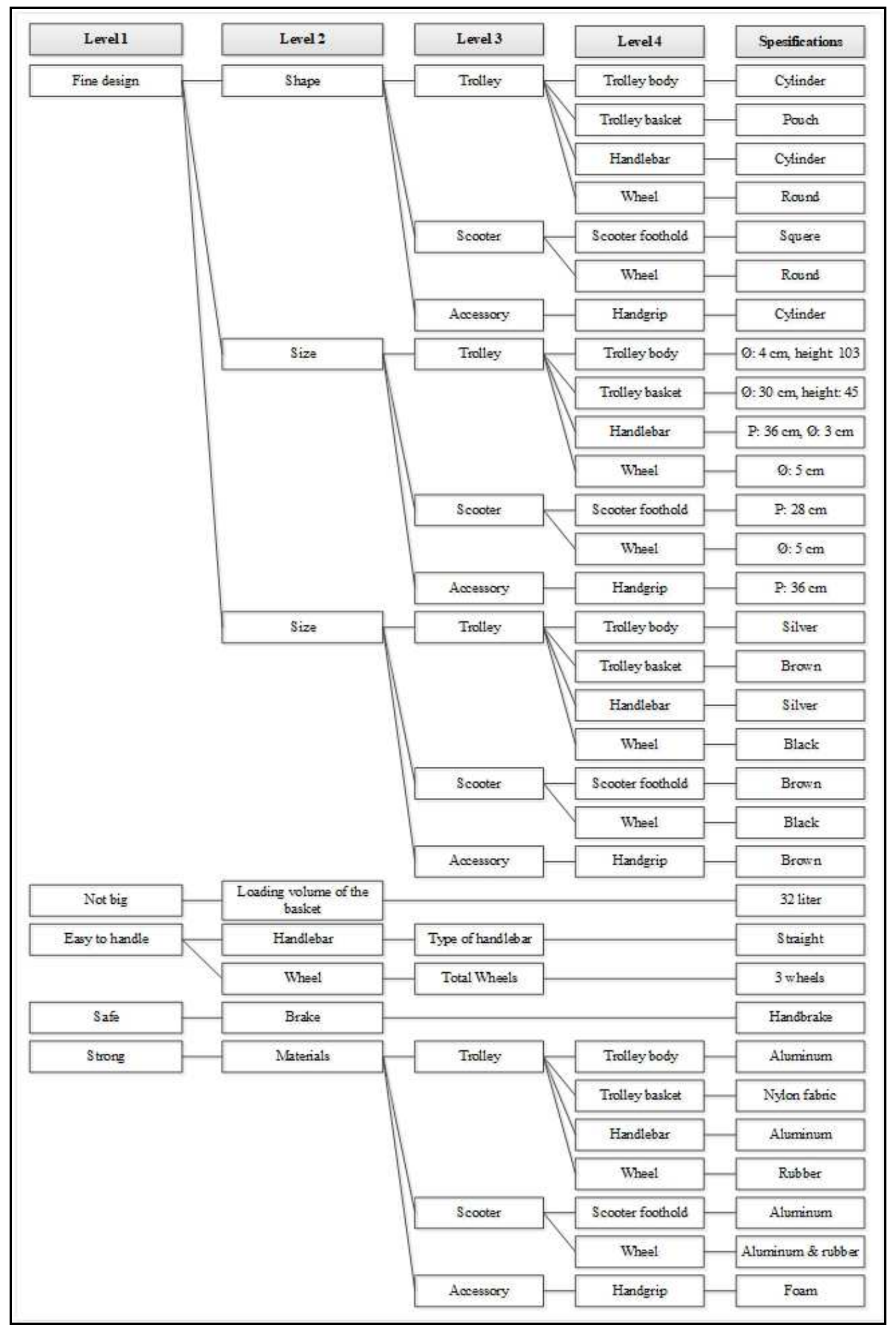

Fig. 2 Products mapping

\section{Visualization of Design Concept}

Once the specifications of each of the words Kansei have been obtained, the next step is to visualize the results of the design concepts that have been made. The design concept created can be seen in Figure 3 and Figure 4 below. 


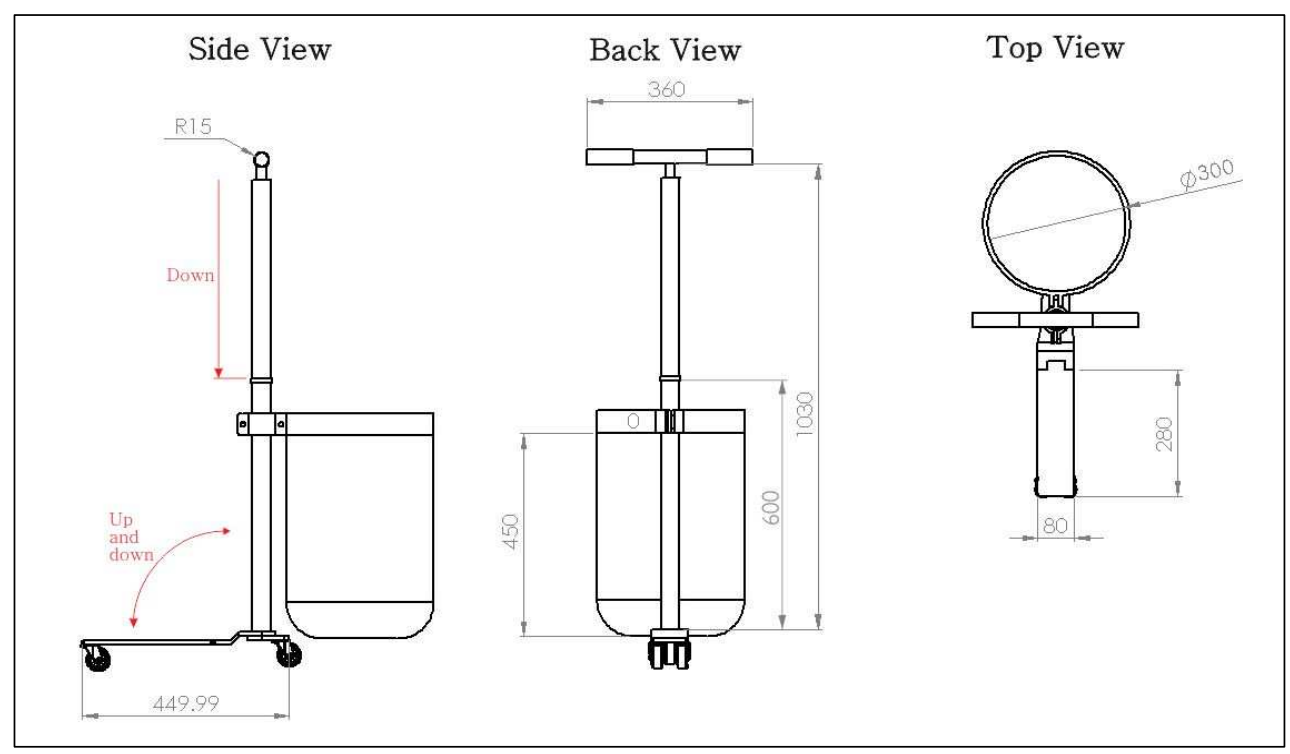

Fig. 3 Visualization of Design Concept

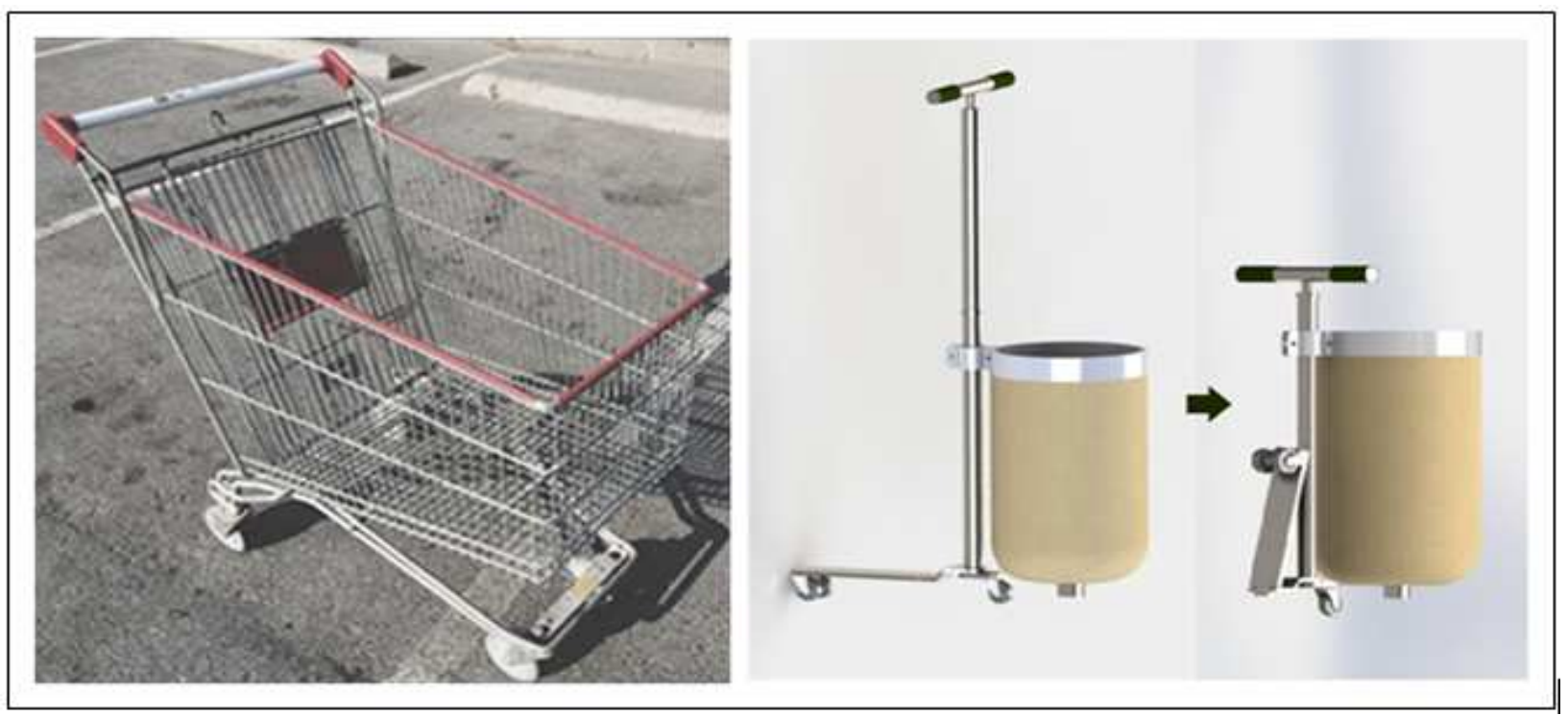

Fig. 4 Old design and proposed shopping trolley design

\section{E. Design Validation}

This step is done to find out the gap or the difference between design concepts made with customers wants. This step is done after the concept of the design is visualized into a form of the product. The test is done by using Stuart Maxwell test of marginal homogeneity, and the result of this test can be seen in Table VI below.

TABLE VI

Result of STUART MAXWELl TEST

\begin{tabular}{|l|l|}
\hline Kansei Words & Z-Value \\
\hline Fine design & 0.317 \\
\hline Not big & 0.071 \\
\hline Strong & 0.225 \\
\hline Easy to handle & 0.251 \\
\hline Safe & 0.059 \\
\hline
\end{tabular}

Value of these five Kansei words is declared as valid because Z-value $>0.05$. It shows that the concept design made has already met the customer's wants [16].

\section{CONCLUSION}

From the result of this research can be concluded as follow: (a) Kansei words that represent customer's wants in designing a shopping trolley with the scooter are fine design, strong, easy to handle, not big and safe. (b) The concept design made has already meet customers wishes with Zvalue of Stuart Maxwell test of marginal homogeneity greater than 0.05 .

\section{ACKNOWLEDGMENT}

The writer sends a lot of gratitude to Universitas Islam Indonesia, especially to Master Study Program of Industrial Engineering, Faculty of Industrial Technology, Universitas Islam Indonesia, and every party who had been a big help in this research and make it come true. 


\section{REFERENCES}

[1] G. C. M. Tamyn, Yulia, and J. Andjarwirawan, "Aplikasi informasi promo pusat perbelanjaan di Surabaya berbasis iOS," Jurnal INFRA, vol. 6 , pp. 1-5, 2018 .

[2] L. Newington, E. C. Harris, and K. Walker-Bone, "Carpal tunnel syndrome and work," Research Clinical Rheumatology, vol. 29, pp. 440-453, 2015

[3] N. D. Astuti, "Perancangan Troli Belanja Yang Praktis dengan Tempat Duduk Bermotor Bagi Manula," Undergraduate Thesis, University of Surabaya, Surabaya, Indonesia, 2015.

[4] G. S. Putra, S. Martini, and M. Iqbal, "Design supermarket trolley using implementation Kansei engineering method," in e-Preceeding of Engineering, 2017, vol. 4.2, p. 2453.

[5] H. Narula, M. Shah, and S. Roke, "Smart shopping cart using a product navigation system," IJETR, vol. 2, pp. 206-209, 2014

[6] S. Schütte, "Designing feelings into products: integrating Kansei engineering methodology in product development," Undergraduate Thesis, Linköpings Universitet, Linköping, Sweden, 2002.

[7] H. Sihombing, M. Y. Yuhazri, S. H. Yahaya, and F. Syaifoelida, "The Kansei design characteristics towards learning style," Journal of Engineering, vol. 2013, pp. 1-29, 2013.

[8] M. Nagamachi and A. M. Lokman, Kansei engineering: a beginner's perspective, Tokyo: KDRU Publishing, 2009.

[9] M. Nagamachi, "Kansei Engineering: A New Ergonomic ConsumerOriented Technology for Product Development," Int. J. Ind. Ergon, vol. 15, pp. 3-11, 1995.

[10] T. Yogasara, J. Valentino, "Realizing the Indonesian national car: the design of the $4 \times 2$ wheel drive passenger car exterior using the Kansei engineering type 1," IJTech, vol. 2, pp. 338-351, 2017.

[11] C. Okada, H. Iso, J. Ishihara, K. Maruyama, N. Sawada, and S. Tsugane, "Validity and Reliability of a Self-Administered Food Frequency Questionnaire for the JPHC Study: the Assessment of Amino Acid Intake,” J. Epidemiol, vol. 27, pp. 242-247, May. 2017.
[12] J. H. Shi, L. Liu, and Y. Q. Li, "Reliability and validity of an indicator system for assessing the quality of ophthalmic nursing," Chinese Nursing Research, vol. 3, pp. 158-161, 2016.

[13] T. Mankan, B. Erci, G.B. Turan, and U. Akturk, "Turkish validity and reliability of the diabetes self-efficacy scale," IJNSS, vol. 4, pp. 239-243, 2017.

[14] C. S. Wahyuning, A. Desrianty, R. Rahmawati, "Studi rancangan konsep produk brassiere melalui pendekatan nilai emosi dan perasaan menggunakan kansei engineering method,’Jurnal Itenas Rekarupa, vol. 1, pp. 56-69, 2011.

[15] M. Dadfar and D. Lester, "Cronbach's $\alpha$ reliability, concurrent validity, and factorial structure of the death depression scale in an Iranian hospital staff sample," IJNSS, vol. 4, pp. 135-141, 2017.

[16] A. Shergian and T. Immawan, "Design of innovative alarm clock made from bamboo with Kansei engineering approach," in Agriculture and Agricultural Science Procedia 3, 2015, vol. 3, p. 184.

[17] M. Y. Setiadi, Anizar, Poerwanto, "Usulan alat Bantu pemindahan batako untuk mengurangi risiko musculoskeletal disorders di PT XYZ," Jurnal Teknik Industri FT USU, vol. 13, pp. 37-43, 2013.

[18] S. Yuamita and R. A. Sari, "Usulan perancangan alat bantu untuk meminimalisir kelelahan fisik dan mental pekerja," JITI UMS, vol. 15, pp. 127-138, 2016.

[19] H. Purnomo, Fajriyanto, and R. Mulyati, "Design of school furniture for first-to sixth-grade classrooms in a special region of Yogyakarta Indonesia," J. Ergonomics, vol. 6, pp.1-8, 2016.

[20] H. Setiawan, "Pengaruh proses equal channel angular pressing (ECAP) terhadap kekerasan alumunium 1050 pada penampang melintang dan memanjang sampel," Momentum, vol. 8, pp. 57-63, 2012.

[21] N. H. Sari and Sinarep, "Analisa kekuatan bending komposit epoxy dengan penguat serat nilon," Jurnal Dinamika UNRAM, vol. 1, pp. 1-6, 2011. 